\title{
Spread of Neoheterobothrium hirame (Monogenea), a serious pest of olive flounder Paralichthys olivaceus, to Korea
}

\author{
Craig J. Hayward ${ }^{1, *}$, Jeong-Ho Kim ${ }^{1,2}$, Gang-Joon Heo ${ }^{1,2}$ \\ ${ }^{1}$ Laboratory of Aquatic Animal Diseases, College of Veterinary Medicine, Chungbuk National University, Cheongju, \\ Chungcheongbuk-do 361-763, Korea \\ ${ }^{2}$ Research Institute of Veterinary Medicine, Chungbuk National University, Cheongju, Chungcheongbuk-do 361-763, Korea
}

\begin{abstract}
Neoheterobothrium hirame is a large, blood-feeding gill-worm infecting the highly prized olive flounder Paralichthys olivaceus in Japan. There is strong evidence that this worm is the primary cause of anaemia, a common and serious condition causing losses among both wild and cultured olive flounders. N. hirame was first detected in Japanese waters less than a decade ago, and its population then proliferated and spread throughout most of Japan, except Hokkaido. In neighbouring Korea, olive flounder is the most important species of cultured marine fish, and production currently exceeds that in Japan. However, until now, there have been no reports of any monogeneans or anaemia among olive flounders in Korea. Our survey conducted in 2000 of 100 cultured individuals from 4 provinces revealed 2 immature specimens of $N$. hirame: 1 from a land-based pond-culture system in southern Cheju Island (off the SW coast of Korea) and the other from a floating net cage near Yosu (in the mid-S part of the peninsula). The geographic range of this pathogen may have been enlarged as a result of introduction(s) of infected broodstock from Japan, but this seems unlikely. (The raising of this species in hatcheries developed in Korea in 1985, 7 years before the earliest detection of the worm in Japan.) Low numbers of flounders were also clearly anaemic. This, and the current rarity of $N$. hirame in Korean farms, appears to favour the hypothesis of a more recent, natural dispersal of the worm, during migrations of infected flounder across the narrow and shallow Tsushima and Korea Straits. Regardless of route of entry, we expect this pathogen will have an impact on Korean flounder fisheries equally serious to that being experienced in Japan.
\end{abstract}

KEY WORDS: Bioinvasion · Dispersal $\cdot$ Monogenean $\cdot$ Pest $\cdot$ Anaemia $\cdot$ Neoheterobothrium hirame Resale or republication not permitted without written consent of the publisher

\section{INTRODUCTION}

The most important marine fish cultured in Korea is olive flounder (Paralichthys olivaceus Temminck \& Schlegel 1846), also commonly known as bastard halibut and Japanese flounder. In 1997, over 25000 metric tonnes were produced-more than double the quantity of the second-most produced species (black rockfish Sebastes schlegeli) (Kim 2000). Olive flounder is highly esteemed in NE Asia for raw consumption in

*E-mail: chayward@trut.chungbuk.ac.kr thin slices, and commands a good market price for farmers. However, this species is also known to be susceptible to many pathogens (Kim 2000).

Although Korea is the dominant producer of olive flounder (Hambrey 2000), its diseases have been much better documented in Japan. A new condition, characterised by severe anaemia leading to mortality in both wild and cultured flounder, was reported in Japan by Miwa \& Inouye (1999). These authors also detected virus-like particles in the haematopoietic tissues of affected fish but did not establish a causative link. More recently, however, Yoshinaga et al. $(2000 a, 2001)$ concluded that haematophagia by a large mono- 
genean, Neoheterobothrium hirame Ogawa, 1999 (Diclidophoridae), was very strongly associated with anaemia in both wild and cultured fish. Similarly, Ogawa (2000a) suggested that the sharp decline in the catch of wild flounder in Tottori Prefecture in Japan may have been due to anaemia induced by infections of $N$. hirame.

Because Neoheterobothrium hirame has emerged as a serious pathogen in Japan, the biological characteristics of the worm are now being investigated in detail, with a view to eventual control (Yoshinaga et al. 2000b,c). Despite its economic impact in Japan, and the importance of the culture of olive flounder in neighbouring Korea, there are no reports of this pest outside Japan. However, we suspected that N. hirame may have already reached Korean waters and become established, because of the remarkable proliferation and spread of the pest within Japan, after its initial discovery in the NW of the country (Anshary et al. 2001). In the present study, we aimed to update the known distribution of this pest by surveying olive flounders cultured in various localities in Korea. In addition, we also aimed to document infections of other potential parasitic pathogens among cultured olive flounders.

\section{MATERIALS AND METHODS}

Samples of 100 individual olive flounder cultured at 5 localities in 4 provinces around the southern and eastern coasts of the Republic of Korea were obtained in July, September and October 2000 from fish farmers (Fig. 1). To prevent the loss of mobile and temporary ectoparasites, all fish were preserved immediately after capture in $10 \%$ formalin in 201 polydrum con- tainers and then transported to the laboratory. After $21 \mathrm{~d}$, the fixed fish were transferred to $70 \%$ alcohol for storage until examination. Flounders were measured, and the external surfaces of the skin and fins were examined for attached parasites. The isthmus was then incised to open the operculum and expose the gills, and the surfaces of the gills and inner walls of the operculum were examined grossly for infections with large, adult worms. To detect small and immature parasites, the gills were then dissected out and separated into the 4 arches and examined in Petri dishes containing $70 \%$ alcohol under a dissecting microscope. All sediments (scales, mucous and dissection debris) settling in preservative solutions were also retained and checked for any detached parasites under the microscope. Worm identification was confirmed by mounting specimens on slides in drops of ammonium picrate glycerine under coverslips, and examining hard parts using light microscopy; copepods were identified directly in Petri dishes containing alcohol. Cases where the gills were obviously much paler than the usual dark red were noted, but no attempt was made to grade the shade of colour for each individual fish because samples were stored in alcohol for varying periods before examination.

\section{RESULTS}

We recorded Neoheterobothrium hirame Ogawa, 1999 in Korea for the first time in 2 localities (Table 1): in a land-based pond in southern Cheju Island and in a net cage at Yosu in the central region of the southern part of the Korean Peninsula. Several olive flounders had very pale gills - an obvious symptom of anaemia

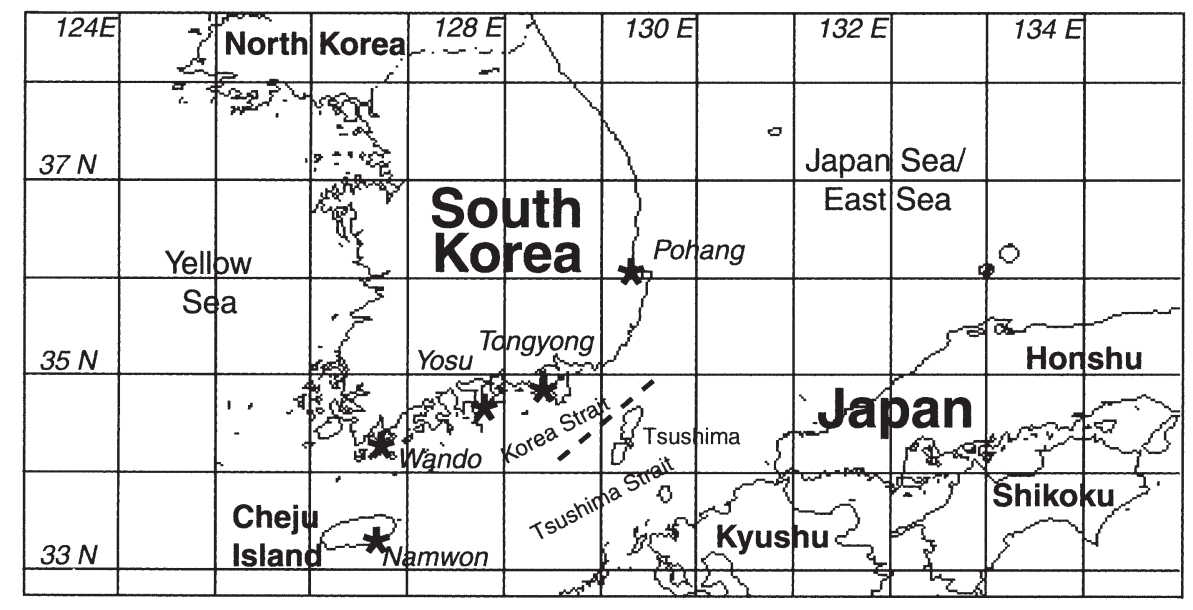

Fig. 1. Sampling sites of olive flounder Paralichthys olivaceus cultured in Korea (*), showing proximity and position of the main islands in the south of Japan 
Table 1. Metazoan ectoparasites and anaemic condition recorded in 2000 from 100 olive flounder Paralichthys olivaceus cultured in 4 provinces in Korea. n: number

\begin{tabular}{|c|c|c|c|c|c|c|}
\hline $\begin{array}{l}\text { Province, } \\
\text { locality (code) }\end{array}$ & $\begin{array}{l}\text { Culture } \\
\text { facility }\end{array}$ & $\mathrm{n}$ & $\begin{array}{l}\text { Length } \\
(\mathrm{mm})\end{array}$ & $\begin{array}{l}\text { Date } \\
\text { in } 2000\end{array}$ & $\begin{array}{l}\text { Anaemic fish } \\
\text { (n) }\end{array}$ & $\begin{array}{c}\text { Parasites } \\
\text { detected (n) }\end{array}$ \\
\hline \multicolumn{7}{|c|}{ Kyongsangbuk-do } \\
\hline Pohang (P2) & Seapool & 12 & $208-303$ & Oct 31 & 0 & - \\
\hline Pohang (P4) & Seapool & 6 & $216-280$ & Oct 31 & 3 & - \\
\hline \multicolumn{7}{|c|}{ Kyongsangnam-do } \\
\hline Tongyong (T5) & Net cage & 1 & 345 & Jul 13 & 0 & $\begin{array}{l}\text { Acanthochondria sixteni (2) } \\
\text { Lernaeopodidae gen. sp. (1) }\end{array}$ \\
\hline \multicolumn{7}{|l|}{ Chollanam-do } \\
\hline Yosu (Y1) & Net cage & 6 & $>250$ & Jul 7 & 0 & Neoheterobothrium hirame (1) \\
\hline Wando (W1) & Net cage & 30 & $106-168$ & Oct 25 & 0 & - \\
\hline \multicolumn{7}{|l|}{ Cheju-do } \\
\hline Namwon (C2) & Inland pond & 15 & $248-358$ & Sep 19 & 0 & - \\
\hline Namwon (C3) & Inland pond & 30 & $200-286$ & Sep 19 & 4 & N. hirame (1) \\
\hline
\end{tabular}

hitherto unreported in Korea. The number of fish with obviously pale gills exceeded the number of hosts in which we detected $N$. hirame; similarly, we recorded anaemia in a locality where we did not detect the worm (Table 1).

In addition, we recorded 2 other ectoparasites, both copepods, from cultured olive flounder for the first time: 2 female specimens of a chondracanthid, Acanthochondria sixteni (Wilson 1922); and a single female specimen of an unidentified genus and species of lernaeopodid. All 3 individuals were removed from the mouth cavity of a single, large net cage-cultured flounder examined from Tongyong (Table 1).

\section{DISCUSSION}

Until now, only 4 ectoparasites have been recorded from olive flounder in Korea: 2 ciliate protozoans (Cryptocaryon irritans, Jee et al. 1996, and an unidentified scuticociliate, see Lee et al. 1994) and 2 caligid copepods (Caligus curtus, Kim \& Lee 1994, and C. brevicaudatus, Choi et al. 1995). The present study increases this figure by 3 , with the addition of $\mathrm{NeO}$ heterobothrium hirame, Acanthochondria sixteni and an unidentified Lernaeopodidae gen. sp. (Table 1). Despite the careful collection of sediments in fixative and storage solutions, we detected neither caligid copepods nor benedeniine monogeneans (Table 1), both of which are common pests of cultured marine fishes.

Of these 7 parasites now known from cultured olive flounder in Korea, only 3 (the 2 protozoans and Neoheterobothrium hirame) have been recorded on the same host cultured in Japan. Ogawa \& Yokoyama (1998) list a total of 8 ectoparasitic taxa afflicting cul- tured olive flounder in Japan: a flagellate (Ichthyobodo sp.), 3 ciliates (Trichodina spp., Cryptocaryon irritans and an undescribed scuticociliate), a gill myxozoan (Kudoa shiomitsui) and 3 monogeneans (Neobenedenia melleni [as syn. N. girellae], Benedenia epinepheli and Neoheterobothrium hirame [as N. sp.]). In addition, a ninth ectoparasitic pathogen is known in Japan-the copepod Lepeophtheirus paralichthydis (Ogawa pers. comm., cited by Ho 2000).

Neoheterobothrium hirame first attaches to the gill filaments, then migrates to the gill rakers and finally moves to the buccal cavity wall, where its attachment also provokes a strong host response (Anshary \& Ogawa 2001), i.e. tissue reaction, not including the loss of blood itself. In the present study, both of the immature specimens detected were found attached to the gill filaments, with no discernible host reaction. On the other hand, not only do adult worms feed on large amounts of blood, but also their haptoral clamps embed deeply in muscle tissue of the opercular wall, causing necrosis of epithelial and muscle tissue, and marked infiltration of inflammatory cells and fibroblasts (Anshary \& Ogawa 2001). Although no adults were detected in the present study, some olive flounder did exhibit very pale gills. This lack of a perfect association between parasite presence and the anaemia seems to suggest the involvement of an additional pathogenic agent - perhaps the 'virus-like particles' described by Miwa \& Inouye (1999) from the haematopoietic tissues of the kidney and spleen of affected hosts. It may well be that $N$. hirame not only induces anaemia directly in hyperinfestations but also may act as a vector of a second anaemia-inducing pathogen. Such a pathogen may even be transmitted vertically from adult $N$. hirame to eggs. 
The population of wild olive flounder in northern Japan probably first became infected with Neoheterobothrium hirame in the early 1990s. Anshary et al. (2001) examined 821 preserved flounders collected in annual samples each summer for over a decade, beginning in 1989, from 2 sites about $50 \mathrm{~km}$ apart in Niigata Prefecture. N. hirame was absent from flounders caught in the first 4 years. The parasite first appeared in 1993, with a very low prevalence (4.5\% off Igarashihama and $2 \%$ off Murakami City). Prevalence then increased in subsequent years, until reaching a peak in $1998(89 \%)$. In the final year, 1999, prevalence then declined to $13 \%$; this may have been because the number of fry was estimated to be 10 times higher than the year before (Anshary et al. 2001). We would expect natural fluctuations in $N$. hirame abundance and prevalence from year to year. However, the dramatic boom in the worm population, at least in the only region investigated in detail (from 0 to $89 \%$ prevalence over a 7 year interval) - accompanied by flounder mortalities (Ogawa 2000a) — seem to indicate that the host population has little if any resistance, and was naïve. Thus, there is little support for the hypothesis that this worm was a previously overlooked, endemic parasite of Japan.

Similarly, we conclude that Neoheterobothrium hirame probably also invaded Korean shores recently. It is possible that $N$. hirame also remained undetected in Korea until now because its populations were at low levels or patchily distributed for a very long period; concurrently, the local research effort in Korea aimed at investigating the parasites of flounder has been less intense than in Japan. However, we believe that it is most unlikely that the worm is endemic in Korea, again because in Japan, where the parasite fauna of wild fish is much better known, the worm was also completely unknown until the early 1990s. Instead, we believe that our finding of this worm in Korea, as represented by just 2 immature specimens among 100 flounders, is indicative of a very recent westward expansion of its distribution.

The dispersal from Japan may have been as a result of accidental introduction(s) in shipments of live flounder for culturing; instead, it appears more likely that it was a result of natural migrations of olive flounders across the narrow and shallow body of water separating the Korean peninsula from western Japan (Fig. 1). We have no evidence to completely rule out the first hypothesis, but we do know that the technology for the large-scale artificial hatchery production of olive flounder in Korea was developed in 1985 (Rho 1996) - 7 yr before the parasite was even detected in Japan. Moreover, Korea exports olive flounder to both China and Japan (Kim 2000), but if infected broodstock or fingerlings from Japan had contaminated Korean culture facilities, then we might expect the worm (and symptoms of anaemia) to have become prevalent in Korean farms already. This would be the case even if farmers had applied chemical treatments, such as formalin-just as has occurred in Japan. Support for the hypothesis of the natural dispersal of Neoheterobothrium hirame to Korea would be strengthened if samples of wild flounders in Korea were found to be heavily infected with $N$. hirame.

Despite its sudden appearance in Japan, we are not aware of speculation on the possible origins of $\mathrm{NeO}$ heterobothrium hirame. Within the past 5 years, this worm has been collected very widely throughout Japan, except in Hokkaido (Ogawa 1999), and we now record it in Korea. Because pleuronectiform fishes are host to various species of Neoheterobothrium (see Ogawa 1999, 2000b), we speculate that the outbreak of $N$. hirame on olive flounder, beginning in 1993 or shortly before (Anshary et al. 2001), seems likely to have been the result of a host-capture or hostswitching event from another lesser-known flatfish inhabiting Japanese waters. On the other hand, $N$. hirame may in fact be a synonym of N. affine (Linton, 1898) because the 2 species can be distinguished only by soft-tissue characters ('relative body size' and 'relative length of isthmus', according to Ogawa 1999). If this is so, this pest may well have been introduced to Japan from North America in shipments of the type host, Paralichthys dentatus, which are imported fresh for the sashimi market.

The only other host-specific monogenean known from olive flounder is Pseudamphibdella paralichthydis Yamaguti 1958. This worm was described from 3 specimens from a wild host from the Inland Sea of Japan caught over 40 years ago. However, despite the examination of several thousands of wild and cultured olive flounders from numerous localities in Japan within the past $10 \mathrm{yr}$, and 100 cultured individuals from Korea in the present study, we have found no reports mentioning this worm again. Such extreme rarity may indicate the extinction of this worm. Alternatively, however, it is possible that the original flatfish host individual of $P$. paralichthydis was simply mistranscribed (or misidentified) as olive flounder.

Acknowledgements. This study was supported by an AsiaPacific Economic Cooperation (APEC) Postdoctoral Fellowship to C.J.H. from the Korea Science and Engineering Foundation. We thank Mr Jin-Seog Seo (Bayer Korea Ltd, Korea), for kindly organising our visits to olive flounder culture facilities in Kyongsangbuk-do, Kyongsangnam-do and Cheju-do. Very special thanks are extended to Mr Hilal Anshary (University of Tokyo, Japan) for discussions with C.J.H. on the ecology of Neoheterobothrium hirame and for his comments on the manuscript. 


\section{LITERATURE CITED}

Anshary H, Ogawa K (2001) Microhabitats and mode of attachment of Neoheterobothrium hirame, a monogenean parasite of Japanese flounder. Fish Pathol 36:21-26

Anshary H, Ogawa K, Higuchi, M Fujii T (2001) A study of long-term changes in summer infection levels of Japanese flounder Paralichthys olivaceus with the monogenean Neoheterobothrium hirame in the Central Sea of Japan, with an application of a new technique for collecting small parasites from the gill filaments. Fish Pathol 36:27-32

Choi SD, Hong SY, Lee JM (1995) Two species of Caligus (Siphonostomatoida, Copepoda) parasite on marine cultured fishes from Kamak Bay in Korea. Bull Natl Fish Res Dev Agency 49:157-166

Hambrey J (2000) Global prospects for cage aquaculture of marine finfish: input costs, market value and comparative advantage. In: Liao K, Lin CK (ed) Cage aquaculture in Asia: Proceedings of the First International Symposium on Cage Aquaculture in Asia. Asian Fisheries Society, Manila, and World Aquaculture Society-Southeast Asia Chapter, Bangkok, p 193-206

Ho JS (2000) The major problem of cage aquaculture in Asia relating to sea lice. In: Liao K, Lin CK (ed) Cage aquaculture in Asia: Proceedings of the First International Symposium on Cage Aquaculture in Asia. Asian Fisheries Society, Manila, and World Aquaculture Society-Southeast Asia Chapter, Bangkok, p 13-19

Jee BY, Park SI, Kim KH (1996) Parasitic ciliates causing white spot disease in cultured flounder, Paralichthys olivaceus. In: The Second Japan-Korea Joint Meeting and Symposium of Aquaculture, July 12-14 1996. National Fisheries University, Shimonoseki, p 133

Kim IB (2000) Cage aquaculture in Korea. In: Liao K, Lin CK (ed) Cage aquaculture in Asia: Proceedings of the First International Symposium on Cage Aquaculture in Asia. Asian Fisheries Society, Manila, and World Aquaculture Society-Southeast Asia Chapter, Bangkok, p 59-73

Kim YG, Lee KK (1994) Study on extermination of Copepoda, Caligus curtus parasitised to culture Paralichthys olivaceus. J Fish Pathol 7:47-51 (in Korean)

Lee NS, Park JH, Han KS, Huh MD (1994) Histopathological

Editorial responsibility: Wolfgang Körting,

Hannover, Germany changes in fingerlings of Japanese flounder, Paralichthys olivaceus, with severe scuticociliatosis. J Fish Pathol 7: $151-160$

Miwa S, Inouye K (1999) Histopathological studies of the flounder with anemia found in various places in Japanese coastal waters. Fish Pathol 34:113-119 (in Japanese)

Ogawa K (1999) Neoheterobothrium hirame sp. nov. (Monogenea: Diclidophoridae) from the buccal cavity wall of Japanese flounder Paralichthys olivaceus. Fish Pathol 34: 195-201

Ogawa K (2000a) Parasitic diseases of fishes in Japan. In: Conference Handbook of the Korean Society of Veterinary Science International Symposium, Taejon, Korea, October 12 , 2000. Korean Society of Veterinary Science, Suwon, p 41-44

Ogawa K (2000b) The oncomiracidium of Neoheterobothrium hirame, a monogenean parasite of Japanese flounder Paralichthys olivaceus. Fish Pathol 35:229-230

Ogawa K, Yokoyama H (1998) Parasitic diseases of cultured marine fish in Japan. Fish Pathol 33:303-309

Rho S (1996) Present status and future direction for seed production of marine fish in Korea. In: The Second JapanKorea Joint Meeting and Symposium on Aquaculture, July 12-14 1996. National Fisheries University, Shimonoseki, p 24

Yoshinaga T, Kamaishi T, Segawa I, Kumagai A, Nakayasu C, Yamano K, Takeuchi T, Sorimachi M (2000a) Hematology, histopathology and the monogenean Neoheterobothrium hirame infection in anemic flounder. Fish Pathol 35: 131-136 (in Japanese with English summary)

Yoshinaga T, Kamaishi T, Segawa I, Yamamoto E (2000b) Effects of NaCl-supplemented seawater on the monogenean, Neoheterobothrium hirame, infecting the Japanese flounder. Fish Pathol 35:97-98

Yoshinaga T, Segawa I, Kamaishi T, Sorimachi M (2000c) Effect of temperature, salinity and chlorine treatment on egg hatching of the monogenean Neoheterobothrium hirame infecting Japanese flounder. Fish Pathol 35:85-88

Yoshinaga $\mathrm{T}$, Kamaishi $\mathrm{T}$, Segawa I, Yamano $\mathrm{K}$, Ikeda $\mathrm{H}$ (2001) Anemia caused by challenges with the monogenean Neoheterobothrium hirame infecting Japanese flounder. Fish Pathol 36:13-20

Submitted: February 9, 2001; Accepted: April 25, 2001

Proofs received from author(s): July 18, 2001 